\title{
Reflection on the Albanian Legislation and Reforms Relevant to Leadership of School in the Pre-university Education Cycle
}

\author{
Enida Kume
}

\section{ABSTRACT}

Leadership reform is one of the main components of reforms in the preuniversity education system in Albania. The changes in the legislative framework aim at building an integral model of leadership capable of acting in the conditions of an open and global society. These changes address issues related to capacity building for the formation, continuing training and evaluation of the professional performance of school leadership / principals. Analysis of current legislation and identification of needs for intervention in order to build a legal framework that supports institutional development and infrastructure necessary for the practical implementation of the Integral Model of the director of the educational institution / school in the pre-university education system is the object of this paper.

Keywords: leadership, pre-university education, legislation, reforms

Published Online: February 25, 2021

ISSN: $2736-4534$

DOI : 10.24018/ejedu.2021.2.1.56

\section{Enida Kume}

University Aleksandër Moisiu, Durrës, Albania

(enidak@hotmail.it)

\section{INTRODUCTION}

The realization of the objectives of the pre-university education system depends on the capacities that the system has and on the way of functioning of the educational institutions / schools. Meanwhile, as shown by [9],[12],[20], [28],[32] etc .. the role of leadership, quality of its work for school management are among the factors with essential effects on the functioning of the system. The professional and managerial skills of the school leader, the dedication, the level of commitment and the will that he demonstrates in the implementation of the task, as the head of the institution, determine, to a considerable extent, the success of the work in educational institutions / schools. The director is the main manager for organizing, directing and developing the school activity. The effects of his work are directly reflected in the quality of service and the level of learning in students ([20], [3], [9]) [30] emphasize that leadership is an important factor in the effectiveness of teamwork. The achievement of expectations and objectives in the reforms made in the education system are conditioned, among other things, by factors that are closely related to: (i) the methodology applied by the leadership for the organization and management of work in the institution; (ii) the level of his commitment to the continuous improvement of the professional performance of the team; (iii) research and implementation of new teaching methods; (iv) leadership efforts to foster and develop a spirit of collaboration between teachers, students, and the community ([2], [4], [5], [7], [8], [18], [19], [27], [28], [29], [31]).

According to [21] the results that students achieve about $60 \%$ are a consequence of the impact of the work done by the school leadership and teachers, where the director of the institution contributes about 25\%. [15], [17], [18] communicate that in schools that have greater problems and needs, their successful coping is, to a considerable extent, the result of the work of the principal. In practice, there are no cases when facing and overcoming the difficulties and problems faced by schools during their activity has passed without the need to have at the head of the school a talented director and manager with high professional training [15].

The qualities and professional skills of leadership are factors with significant effects on the entire activity of educational institutions. According to [28] their effect is not limited to just within the school. Leadership also affects the success of education policies and reforms and in particular: (i) the realization of expectations in the implementation of the reformed methodology for system development; (ii) design and implementation of programs and curricula; (iii) the progress of the teaching and learning processes; (iv) developing best classroom and school management strategies; (v) promoting successful human resource management policies in education.

The current trend, globally, is the transformation of the leadership role in schools from organizational manager to leader of the whole learning process [8]. This is a fact that should be well taken into account during the legislative 
process and when drafting policies and reforms that target issues of well-functioning pre-university education system.

Changes in the political and economic system in Albania, which occurred in the early ' 90 s, conditioned the need for a deep legislative, institutional and infrastructure reform in the pre-university education system. Part of this reform is the reconceptualization of the role, duties and responsibilities of the leadership, the director of educational institutions / schools. Their adaptation to the requirements of the reformed pre-university education system, which should provide service in accordance with the requirements of a liberal, open and global society is a process that is taking place in Albania. Analysis of the results of the reform in the legislative framework that deals with issues related to the new model of leadership in educational institutions / schools, the reflection on the results and needs for follow-up of institutional and infrastructure reforms that have as their objective the development of managerial capacities of leadership in these institutions, are the subject of this paper.

\section{BRIEF OVERVIEW OF THE REFORM OF THE PRE- UNIVERSITY EDUCATION SYSTEM}

During the last two decades in the pre-university education system in Albania complex reform processes have been realized, which have brought fundamental changes in legislation, in the construction and functioning of institutions, conception of programs and curricula, etc .. In this reform process, the objective of which, in the main terms, has been and remains the adaptation of the preuniversity education system to the requirements of the political, economic and social system of the country and its approximation with the education systems in EU countries, can be distinguished three main phases:

1) The phase of correcting the content, purpose and objectives of the education system

2) The phase of preparations for reforms, based on law no. 7952, dated 21.06.1995, "On the Pre-University Education System in the Republic of Albania"

3) Reform phase, based on law 69/2012, dated 21.06.2012 "On the pre-university education system in the Republic of Albania" - 2012 onwards.

In the first phase, the aim was to "cleanse" the system by the "heritage" and influences of communist ideology. The main achievements at this stage are the liberation of the curriculum from political manipulations and ideological distortions, the relative reduction of the teaching load, the better balance of knowledge, skills and attitudes, the revision of the objectives and contents of social subjects, and the introduction of some new subjects (informatics, civic education) etc.

In the second phase, the aim was to prepare the legal basis to support reforms for change in the pre-university education system. Durning this phase the quality of the curriculum, contemporary experiences and recent developments was analyzed. Cooperation with foreign organizations and the World Bank was deepened. With their help and expertise two national education strategies were drafted. To implement these strategies two national projects were implemented (2000-2005; 2006-2010). Aims and objectives was the changes that should affected the structure of the education system, the curriculum and the management systems. But, despite the efforts and investments, the assessments of national and international agencies showed that the quality of pupils achievement was not at the level of expectations and that the pre-university education system had weaknesses and low effectiveness.

In the third phase, the policies and reforms undertaken aim at developing the capacities in the pre-university education system, in order to approximate it, as much and as well as possible, with the systems that implemented in the countries with developed democracies. The reform aims to build a democratic education system, which will enable the implementation of the requirements and the basic principles of equality of opportunities for quality education, as well as respect for individual differences.

Reforms in the pre-university education system are conceived and implemented in accordance with the vision according to which:

1) at the center of the system should be the pupil with his needs and interests, a system completely different from the traditional system, which has treated the student as a subject that had to be mechanically adapted to sistem requirements;

2) pupils, teachers and the community work together to achieve objectives in preparing future citizens, in an open and global society;

3) pupils must possess the knowledge and competencies to enable them to solve problems and face the challenges they may face in life

4) cultural and linguistic diversity, inclusion and developments in information and communication technologies, are an integral part of the education system, the formation and preparation of students.

\section{ANALYSIS OF THE CURRENT LEGISLATIVE FRAMEWORK RELATED TO LEADERSHIP AND PRINCIPAL ISSUES IN EDUCATIONAL INSTITUTIONS / SCHOOLS IN THE PRE-UNIVERSITY EDUCATION SYSTEM}

The first important act in the legislative reform related to the pre-university education system, is the approval of Law No. 7995 No. 7952 , dated 21.6.1995 "On the pre-university education system". In the following period, the parliament and the government have adopted laws and bylaws which are the basis of policies and reforms for the pre-university system in Albania. Part of them are the legislative framework that deals with issues related to leadership, directors of educational institutions, professional profile, their duties and rights, professional competencies and standards, evaluation and ongoing qualification in them, etc ... Based on this legal framework, strategic documents have been drafted and approved, the implementation of which aims to build the preuniversity education system in Albania, aligned with the education systems in EU countries, capable of preparing citizens to face the challenges of global economic, social and cultural environment.

Law no. 69/2012, dated 21.06.2012, "On the preuniversity education system in the Republic of Albania", as amended, is the main legal document that regulates the status of school director. The law in article 54 defines the head of the educational institution as his central figure. The director is responsible for the management of the educational institution, for the quality of the educational service and its continuous improvement as well as for the design and implementation of the curriculum. He is in charge of managing personnel and material and financial resources, organizing and developing cooperation with the community 
and public institutions responsible for education, at the local and central level.

The inclusion of the director of the pre-university educational institution in the national list of professions ${ }^{1}$ is a development with positive effects on the quality of his organizational, managerial and managerial work.

Article 55 "Appointment and dismissal of the director of the educational institution" in Law no. 69/2012, dated 21.06.2012 is legal basis that has regulated a process which, as a result of political interference, has always been problematic in Albania. The provision requires that the decision be the result of objective evaluation and judgment, supported and only on the basis of fulfillment, by the relevant person, of the professional criteria set, principles and norms of the Code of Ethics. According to this provision the head of the local educational institution, responsible for the pre-university education, has the right to appoint the director of an educational institution/school. This decision is made based on the proposal for two candidates, who are evaluated, with an open competition.

The law provide that the certification of a candidate for director in an educational institution should be performed after the development of mandatory preparatory training in the School of Directors ${ }^{2}$. Referring to the conditions of the Albanian society, the provision has brought another development, welcome - the head of the educational institution can not be a member of the forums of political parties.

The provision stipulates that the dismissal of the director is done by the head of the local educational institution, responsible for pre-university education, in cases when it is proven that he has violated the provisions of the law on preuniversity education, bylaws adopted for its implementation, has violated the Code of Ethics of Behavior in the institution, as well as for non-realization of the objectives of the institution.

Employment criteria are mandatory for directors of public and private institutions.

For the implementation of this provision, the Ministry of Education has approved Instruction no. 57, dated 12.11.2013 "On the procedures of appointment and dismissal of the director of the public institution of pre-university education".

The analysis of the observations made for the implementation of this legal framework shows that in practice there are problems. In most of them these problems are related to the composition and functioning of the evaluation commission and the lack of standardized procedures for evaluating the professional performance of the school principal.

Recent amendments to the law on pre-university education, approved by law no. no.48 / 2018 "On changes in law no. 69/2012 ..." have provided rules for training and professional development of leadership/director in educational institutions of the pre-university education system. According to this law, the development of vocational training can be realized in several forms: internal professional development, training, professional networks, counseling, short-term courses and long-term courses. The law obliges local educational units to organize the continuous

\footnotetext{
${ }^{1}$ Decision of the Council of Ministers no. 514, dated 20.9.2017, "On the approval of the national list of professions (LKP), revised".

${ }^{2}$ Law no. 48/2018 dated 23.07 / 2018. Article 27/1 School of Directors

1. "School of Directors" is a legal entity, which aims at the professional

development of directors and candidates for directors of pre-university
}

professional development of teachers in cooperation with training agencies, with accredited training programs, selected through open competition, according to the procedures provided in the instruction of the Minister. The financial resources for the trainings are provided from the personal contribution of the educational employee and the state budget or through grants provided by the non-profit organization, local or foreign foundations ect.

\section{NEVOJA PËR REFORMË NË KUADRIN LIGJOR PËR FORMIMIN, ZHVILLIMIN DHE VLERËSIMIN E PERFORMANCES SE DREJTORIT}

The compilation of rules for the formation, development and evaluation of the performances of the director is considered and treated as an important issue in the three phases of the process of reforming the pre-university education system in Albania. This is an evolving process Part of it is the developments in legislation and reforms that need to be made to increase institutional capacities and in infrastructure. Their coordination with the interventions in the legislation that regulates the activity of central and local institutions and with the reform for decentralization, are necessary.

Referring to the current situation and responding to the needs and trends in medium-term developments, drafting a complete package of rules, instruments and standards to be met for the formation, development and evaluation of leadership and directors performances in educational institutions in the preuniversity system of education, is identified as a requirement of the time. Building an integrated leadership model should be considered as one of the important objectives of leadership reform for this system. The model should reflect the standards that serve for performance evaluation. To build such a leadership model it is recommended that decision makers and policy makers refer to domestic and foreign best practices. According to [7], [16] the integrated leadership model should be built in accordance with the requirements for developing a shared vision, reaching consensus with staff and the community on school objectives, and striving to meet expectations for high performance. From the point of view of management principles, according to [6], [22] the model must be based on two opposing principles: coordination of work and obligation to implement.

The reform of the Integrated Leadership Model should be conceived in such a way that, implemented in practice, it results in the formation of a leadership in educational institutions / pre-university education schools that is capable of:

1) work according to a clear and comprehensive vision, in accordance with the strategic priorities of the education system and the needs of different stakeholders

2) to manage the activity of the institution focusing on creating a supportive environment for the teaching and learning processes, closely related to the strategic objectives and specific characteristics of the school

3) understand and manage the links between the objectives of the institution, the organizational environment and the quality of teaching

educational institutions, public or private, administration of the mandatory preparatory training process for obtaining a certificate for the management of pre-university educational institutions and continued leadership training. 
4) to demonstrate a high level of motivation and responsibility for achieving the objectives of the institution for the continuous improvement of the teaching service, the well-being of students and the inclusiveness

The analysis of the National Report "Identification of training needs of school leaders and teachers in the preuniversity education system" (2016) highlights the need to develop an integral reform for institutional capacity building and infrastructure for continuous professional development of principals. Interventions in legislation should also be part of this reform. It is necessary to compiled a legal framework, which should addressed the duties and responsibilities of all institutions, public and private, that may or should be involved in the processes of formation, continuous development of professional competencies of directors and their evaluation.

Interventions in legislation to build a supportive legal framework for leadership reform in the pre-university education system should be made aiming at:

1) To build the methodology and a bylaws framework for supporting the continuous professional development of leadership

2) Drafting standards and professional competencies of leadership, necessary to implement policies and to lead and manage the activities of the educational institution.

3) Drafting rules and procedures for evaluating the effectiveness of leadership work for the administred and management of the educational institution / school

4) Development of leadership training programs to design and successfully implement personal plan for continuous professional development

5) Institutionalization of the process of monitoring and periodic evaluation of the director of the educational institution / school, according to a performance-based system

\section{CONCLUSIONS}

Albanian legislation considers leadership, school director, as an important factor for the performance of tasks and mission that have the educational institutions / schools in the pre-university education cycle

Changes in legislation and reforms carried out in the preuniversity education system after the '90s of the last century, have reconfigured the leadership model in the institutions of this system, adapting it to the requirements of an open and global society.

In order to increase the role of the school leadership / principal, changes in the legislative framework that addresses issues of training, continuing qualification and evaluation of the professional performance of the school leadership / principals are necessary.

Reforms in the pre-university education system should address more and more comprehensively the issues related to institutional developmet and strength the infrastructure capacities, necessary for implementation of the leadership intergated model.

\section{REFERENCES}

[1] Barth, R. S. (1990). Improving schools from within: Teachers, parents, and principals can make the difference. San Francisco: Jossey-Bass. https://doi.org/10.1002/15206807(199301)30:1<99::AID-PITS2310300117>3.0.CO;2-J

[2] Beteille, T., Kalogrides, D., \& Loeb, S. (2009). Effective Schools: Managing the Recruitment, Development, and Retention of HighQuality Teachers. Washington D.C.: The Urban Institute. https://www.issuelab.org/resources/7137/7137.pdf

[3] Bezati, F. (2012) Faktorët që ndikojnë në kënaqësinë e punës së mësuesve të arsimit bazë në Shqipëri. Tezë doktorature, Universiteti i Tiranes, Fakulteti i Shkencave Sociale, Tirane, Shqiperi.https://www.yumpu.com/xx/document/view/38241991/d oktoratura-fatmir-bezati-fakulteti-i-shkencave-sociale

[4] Day, C., Harris, A., Hadfield, M., Tolley, H., \& Beresford, J. (2000). Leading schools in times of change: A multiperspective study of effective headteachers. Buckingham: Open University Press. http://www.leeds.ac.uk/educol/documents/00001242.htm

[5] Day, C., Sammons, P., Leithwood, K., Hopkins, D. Gu, Q. \& Brown, E., with Ahtaridou, E. (2011). Successful School Leadership: Linking with Learning and Achievement. Maidenhead: McGraw Hill Open University Press.http://journals.sfu.ca/jmde/index.php/jmde_1/article/viewFil e/401/380

[6] Drucker, P.F. (2008). Management. Revised Edition. New York: Collins Business. https://www.academia.edu/35149943/Peter_F_Drucker_Managem entRev_Ed

[7] Hallinger, P. (2003) Leading Educational Change: reflections on the practice of instructional and transformational leadership Cambridge Journal of Education Vol. 33, No. 3, November 2003. https://www.semanticscholar.org/paper/Leading-EducationalChange\%3A-reflections-on-the-of-

Hallinger/31a3f081356e30b51064904a5a033d0c843f812f

[8] Hallinger, P. (2011). Leadership for learning: Lessons from 40 years of empirical research. Journal of Educational Administration, 49(2), 125-142. https://www.emerald.com/insight/content/doi/10.1108/095782311 11116699/full/html

[9] Hayes, D., Mills, M., Christie, P. \& Lingard, B. (2006). Teachers \& Schooling: Making A Difference. New South Wales: Allen \& Unwin. https://www.scirp.org/

[10] Hysa, F. (2020) Lidershipi dhe performanca e shkollës https://www.researchgate.net/publication/343524677_Lidershipi_ dhe_performanca_e_shkolles

[11] Instruction No. 57, dated 12.11.2013 "On appointment procedures and dismissals of the directors in pre-university education public institutions"

[12] Jaupi, K. (2015) Lidershipi në arsim https://portalionline.com > lidershipi-ne-arsim

[13] Labovitz, G. \& Rosansky, V. (1997). The Power of Alignment: How Great Companies Stay Centered and Accomplish Extraordinary Things. New York: Wiley \& Sons. ISBN: 978-0471-17790-6

[14] Law no. 69/2012, dated 21.06.2012 "On Pre-university education in the Republic of Albania", as amended by Law no. 56/2015 dated 28.5.2015 and Law no. 48/2018 dated on 23.07/2018. http://www.parlament.al/Files/ProjektLigje/20181126124532ligj $\% 20 \mathrm{nr} . \% 2048, \% 20 \mathrm{dt} . \% 2023.7 .2018 . \mathrm{pdf}$

[15] Leithwood, K. \& Jantzi, D. (2005). A Review of Transformational School Leadership Research 1996-2005. Leadership and Policy in Schools, 4(3), 177-199. http://dx.doi.org/10.15405/epsbs.2016.09.64

[16] Leithwood, K. \& Jantzi, D. (2008). Linking Leadership to Student Learning: The Contributions of Leader Efficacy. Educational Administration Quarterly, 44(4), 496-528 https://doi.org/10.1177/0013161X08321501

[17] Leithwood, K., Harris, A. \& Strauss, T. (2010). Leading School Turnaround. San Francisco, CA: Jossey-Bass. https://assets.thalia.media/doc/88/83/88833f97-725a-4bbe-bdfb7079fa514a4a.pdf

[18] Leithwood, K., \& Louis, K. S. (2012). Linking leadership to student learning. San Francisco, CA: Jossey-Bass. https://eric.ed.gov/?id=ED527262

[19] Louis, K.S. (2015). Linking leadership to learning: state, district and local effects. NordSTEP, 1(3),7-17. https://doi.org/10.3402/nstep.v1.30321

[20] MacNeil, A.J., Prater, D.L., \& Busch, S. (2009). The effects of school culture and climate on student achievement. International 
Journal of Leadership in Education, 12(1),73-84 https://doi.org/10.1080/13603120701576241

[21] Marzano, R.J., Waters, T. \& McNulty, B.A. (2005). School Leadership that Works: From Research to Results. Alexandria, VA: ASCD https://eric.ed.gov/?id=ED509055

[22] Mintzberg, H. (1996). Ascesa e declino della pianificazione strategica. Torino: ISEDI. https://www.amazon.it/Ascesa-declinodella-pianificazione-strategica/dp/8880080393

[23] Minister of Education Instruction No. 57, dated 12.11.2013 "On appointment procedures and dismissals of the directors in preuniversity education public institutions"; Available at: https://arsimi.gov.al/wpcontent/uploads/2016/01/Permbledhje LAPU1-.pdf

[24] Minister of Education Instruction No.1, dated 20.1.2017 "On the Functioning of the Continuous Professional Development System of Educational Workers". Available at: https://app.box.com/s/yib1g91ol7q1zof7zlic7g1v90u0ase1

[25] National report: Needs assessment on principals and teachers of schools of pre-university education, 2016 https://arsimi.gov.al/wp-content/uploads/2018/03/Raporti_-

[26] Nathanaili, V. (2017) Drejtori i shkollës i shek. XXI. Çështje aktuale të lidershipit dhe të politikës. ISBN 978-9928-127-02-0 Albanian University Press. https://www.valbonanathanaili.com/drejtori-i-shkolles-i-shek-xxiceshtje-aktuale-te-lidershipit-dhe-te-politikes/

[27] Robinson, V., Lloyd, C., \& Rowe, K. (2008). The impact of leadership on student outcomes: An analysis of the differential effects of leadership types. Educational Administration Quarterly, 44(5), 635-674. http://www.sciepub.com/reference/101607

[28] Saramati, E. (2018) Arsimi, trajnimi dhe politika e punës së udhëheqësit arsimor. https://www.facebook.com/Lidershipi-nearsim-478341388865017/posts

[29] Vidoni, D., Bezzina, C., Gatelli, D., \& Grassetti, L. (2007). The Role of School Leadership on Student Achievement: Evidence from TIMSS 2003. JRC Scientific and Technical Reports. European Commission, Ispra: Italy. ISBN: 978-92-79-08111-8. https://publications.jrc.ec.europa.eu/repository/bitstream/JRC4280 2/eur\%2023072\%20en.pdf

[30] Zaccaro, S. J., Rittman, A. L., \& Marks, M. A. (2001). Team leadership. Leadership Quarterly, 12(4), 451483.https://www.coursehero.com/file/p7ku635/Zaccaro-S-J-

Rittman-A-L-Marks-M-A-2001-Team-leadership-LeadershipQuarterly-12/

[31] Xhomara, N. (2012) Development of leadership in school, Revista Pedagogjike. Institute of Education Development, Tirana. Albania.

[32] Xhomara, N. (2015) Professional development of teachers focusing on assessment methodsapplying in science curriculum. October 2324, $2015 . \quad$ Shkodra university. http://konferenca.unishk.edu.al/icrae2015/.

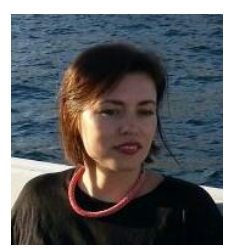

Assoc.

In the period 2009-2019 she worked as a specialist in the Ministry of Education, Youth and Sports. Currently is a full-time academic staff at the Faculty of Education, "Aleksandër Moisiu" University of Durrës, Albania. She is the author of 14 scientific articles published in scientific journals and participant in 21 international scientific conferences. She is the author of a monography.
Enida Kume Prof. Asoc. Dr. completed her university studies, Bachelor in "Social Work" and Master of Science in "Organization and Programming of Social Policies" at the University of Turin, Italy 2003-2008. He completed his postgraduate and doctoral studies at the Faculty of Social Sciences, University of Tirana, in the period 2010-2014

In 2016 he was awarded the academic title Prof.

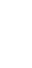

